\title{
18: 44731079-44700221
}

National Cancer Institute

\section{Source}

National Cancer Institute. 18:44731079-44700221. NCI Thesaurus. Code C45052.

Physical location of MADH7_Gene 